\title{
Stool and urinary sugars in normal neonates
}

\author{
R. COUNAHAN and J. WALKER-SMITH \\ From Queen Elizabeth Hospital for Children and the Mother's Salvation Army Hospital, London
}

\begin{abstract}
Counahan, R., and Walker-Smith, J. (1976). Archives of Disease in Childhood, 51, 517. Stool and urinary sugars in normal neonates. The $p H$ of the stool and the amount of reducing substances present were observed in 51 normal neonates aged 5 to 8 days. A stool $p \mathrm{H}$ of 5 or less was found in 6,4 of whom were exclusively breast fed. Reducing substances, $0.5 \%$ or more, were found in the stools of 16 . Stool chromatography in 13 showed lactose, glucose, galactose, or a variable combination of these sugars-that is, a pattern consistent with lactose malabsorption. The stools of 3 infants contained oligosaccharides or maltose only.

Chromatography of urine from 60 normal neonates showed detectable sugars in 11 but only $3 \mathrm{had}$ levels above $50 \mathrm{mg} / 100 \mathrm{ml}$.
\end{abstract}

Reports on the sugar content of the stools and urine of normal neonates are conflicting, though in older children more than $0.5 \%$ of reducing substances in the stools or more than $15 \mathrm{mg} / 100 \mathrm{ml}$ in the urine are generally agreed to be abnormal (Kerry and Anderson, 1964; Menzies and Seakins, 1969). Davidson and Mullinger (1970) examined the stools of 144 normal neonates, both breast and bottle-fed, aged 3 to 7 days, using Clinitest tablets (Kerry and Anderson, 1964), and found more than $0.5 \%$ reducing substances in 65 out of 133 stools, 21 containing $2 \%$ reducing susbstances. Yet Soeparto, Stobo, and Walker-Smith (1972) did not find levels above $0.5 \%$ in the stools of 11 normal neonates.

Bickel (1961), studying 155 specimens of urine from 88 normal neonates, found the mean 'normal' lactose to be between $20 \mathrm{mg} / 100 \mathrm{ml}$ and $50 \mathrm{mg} / 100$ $\mathrm{ml}$ between the third and seventh day of life. Haworth and McCredie (1956) found that about half of 50 normal breast-fed babies had reducing sugars in their urine at some time during the first weeks of life and a substantial minority had more than 50 $\mathrm{mg} / 100 \mathrm{ml}$, yet more than $15 \mathrm{mg} / 100 \mathrm{ml}$ of sugar in the urine of neonates who have had surgery has been regarded by some workers as confirming a diagnosis of sugar intolerance (Howat and Aaronson, 1971).

Thus, though clinical diagnosis of sugar malabsorption in the newborn is usually based on finding an excess of reducing susbstances in a watery stool, what constitutes an excess is at present uncertain. In view of this we undertook a study of stool and

Received 23 October 1975. urine sugar levels in normal breast- and bottle-fed newborn infants. This paper reports the results.

\section{Patients and methods}

Specimens of stool or urine, or both, were obtained from 73 infants in the lying-in wards of the Mother's Salvation Army Hospital, Clapton. At the time of collection 53 of the infants were 5 days old, 17 were 6 days old, 2 were 4 days old, and 1 was 8 days old. Stools alone were collected from 13 infants, urine alone from 22 and both stools and urine from 38 . Their birth weight ranged from 2.3 to $4.2 \mathrm{~kg}$ (mean $3.19 \mathrm{~kg}$ ) and their gestation from 35 weeks to 42 weeks (mean $38 \cdot 1$ weeks).

Feeds were classified as breast, bottle (in all cases prepacked half cream Cow and Gate), and mixedthat is, breast-fed plus complements of half cream Cow and Gate. This formula contains $7 \cdot 1 \mathrm{~g}$ lactose $/ 100 \mathrm{ml}$ but no sucrose.

Urine was collected at random times into U-bags (Hollister) and then deep-frozen in plastic bottles. Stools were collected on the same day into a nappy lined with plastic and were stored in plastic containers in a deep-freeze within 2 hours, in most cases. There was no absolute certainty that stools were not contaminaed by urine, although every endeavour was made to avoid this. The converse could easily be seen on inspection of the urine container at the time of testing and any faecally contaminated specimen was discarded.

After thawing, stool and urine specimens were first tested for reducing substances with Clinitest tablets (Kerry and Anderson, 1964). One part stool was homogenized with about twice its volume of water and then centrifuged; 15 drops of the supernatant were placed in a test tube and a Clinitest tablet (Ames Co.) added, producing a colour change dependent on the concentration of reducing substances. The results were 
recorded as $0.5 \%, 0.75 \%, 1 \%$, and $2 \%$. Urine after thawing was examined in the routine manner with Clinitest tablets. stool $p \mathrm{H}$ was measured with $p H$ paper (Johnson's) by direct contact with undiluted stool. Urine $p \mathrm{H}$ was not measured. Chromatography of urine was performed for every specimen examined but stool chromatography was performed only when $0.5 \%$ or more reducing substances were present. Descending one-way paper chromatography was used to separate the stool and urine sugars : $10 \mu \mathrm{l}$ of stool extract or urine as prepared for Clinitest were spotted on to Whatman 3 MM paper; ethyl acetate, pyridine, and water $(12: 7: 2)$ were used as solvent; and a run of 18 hours with paper length of $41 \mathrm{~cm}$ achieved adequate separation of those sugars commonly found (Menzies, 1973). The papers were thoroughly dried in a current of air and the sugars located by dripping through a reagent ( $P$-anisidine $5 \mathrm{~g}$, orthophosphoric acid $30 \mathrm{ml}, 80 \%$ methanol to 1 litre) followed by heating in an oven for 10 minutes at $80^{\circ} \mathrm{C}$. Suitable standard solutions were run with each batch of unknowns, so that visual quantification of the sugars in the specimens could be made. Stools containing visible spots of sugar were considered positive on chromatography. Oligosaccharides and lactulose were not quantified but their presence was noted.

\section{Results}

Stool pH. Stool $p \mathrm{H}$ was measured in 51 infants -of whom 30 were boys and 21 were girls, and 12 were breast-fed, 30 bottle-fed, and 9 had mixed feeds. The stool $p H$ varied from 4 to 8 (mean $6 \cdot 6)$ and a greater proportion of breast-fed infants had a $p H$ lower than the mean (Table I). Out of the

\section{TABLE I}

Stool $\mathrm{pH}$ and method of feeding in 51 neonates

\begin{tabular}{c|c|c|c|c}
\hline $\begin{array}{c}\text { Stool } \\
p H\end{array}$ & $\begin{array}{c}\text { No. } \\
\text { neonates }\end{array}$ & $\begin{array}{c}\text { No. } \\
\text { breast-fed }\end{array}$ & $\begin{array}{c}\text { No. } \\
\text { bottle-fed }\end{array}$ & $\begin{array}{c}\text { No. } \\
\text { mixed-fed }\end{array}$ \\
\hline 8 & 6 & - & 4 & 2 \\
7 & 26 & 5 & 18 & 3 \\
6 & 13 & 3 & 7 & 3 \\
5 & 5 & 3 & - & - \\
4 & 1 & 1 & - & 9 \\
\hline Total & 51 & 12 & 30 & 9 \\
\hline
\end{tabular}

12 breast-fed babies 4 had a stool $p \mathrm{H}$ of $<6$, but out of the 30 bottle fed and mixed-fed babies only one in each group had a stool $p \mathrm{H}$ of $<6$. Sex, weight, and gestational age did not affect stool $p \mathrm{H}$.

Stool Clinitest. In 51 stools tested by Clinitest tablets $0.5 \%$ or more reducing substances were found in $33 \%$ and completely negative results in $41 \%$. Results of $1 \%$ or more were not found in any infant studied. A greater proportion of breastfed babies had reducing susbstances in their stools (Table II), but, again, sex, weight, or gestation did not affect the result.

Stool chromatography. Chromatography was performed on the stools of 16 infants in which there was $0.5 \%$ or more reducing substances. The principal sugars found were lactose, glucose, or galactose in various combinations (Table III). Galactose was the commonest, sometimes alone but usually in association with glucose or lactose. Lactulose or maltose were present in 3 infants. In 5 cases spots with the chromatographic characteristics of oligosaccharides were seen (E. A. Stobo and J. A. Walker-Smith, unpublished). Only 1 of the 5 babies with oligosaccharides in the stool was bottle fed.

Urine Clinitest and chromatography. Chromatography was performed on the urine of 60 infants, of whom 43 also had a Clinitest examination, which was negative. Discernible amounts of sugar were present on chromatography in 11 infants Table IV): 6 were boys and 5 were girls, 7 were 5 days old and 4 were 6 days old. More than $50 \mathrm{mg} / 100 \mathrm{ml}$ sugar was present in 3 and less than $50 \mathrm{mg} / 100 \mathrm{ml}$ in the remainder. Oligosaccharides were not present. There was no consistent relation between the presence of sugar, the type of feeding, sex, weight, or gestation.

Stool and urine chromatography. 4 of the 11 babies who had both stool and urine chromatography performed and had sugar in their urine also

TABLE II

Reducing substances in stools of 51 neonates measured by Clinitest

\begin{tabular}{|c|c|c|c|c|}
\hline $\begin{array}{c}\text { Reducing } \\
\text { substance } \\
(\%)\end{array}$ & $\begin{array}{c}\text { No. } \\
\text { neonates }\end{array}$ & $\begin{array}{l}\text { No. } \\
\text { breast-fed }\end{array}$ & $\begin{array}{c}\text { No. } \\
\text { bottle-fed }\end{array}$ & $\begin{array}{l}\text { No. } \\
\text { mixed-fed }\end{array}$ \\
\hline $\begin{array}{l}- \\
0 \cdot 25 \\
0 \cdot 50 \\
0 \cdot 75\end{array}$ & $\begin{array}{r}21 \\
13 \\
15 \\
2\end{array}$ & $\begin{array}{l}- \\
2 \\
8 \\
2\end{array}$ & $\begin{array}{r}18 \\
7 \\
5 \\
-\end{array}$ & $\begin{array}{l}3 \\
4 \\
2 \\
-\end{array}$ \\
\hline
\end{tabular}


TABLE III

Sugar concentrations found by chromatography in stools of 16 neonates

\begin{tabular}{|c|c|c|c|c|c|c|c|c|}
\hline \multirow[b]{2}{*}{$\begin{array}{c}\text { Case } \\
\text { no. }\end{array}$} & \multirow[b]{2}{*}{ Feed } & \multirow[b]{2}{*}{$\begin{array}{c}\text { Clinitest } \\
(\%)\end{array}$} & \multicolumn{6}{|c|}{ Stool concentration $(\mathrm{mg} / 100 \mathrm{ml})$} \\
\hline & & & Oligosaccharide & Lactose & Glucose & Galactose & Maltose & Lactulose \\
\hline 1 & Bottle & $0 \cdot 50$ & - & 一 & $\longrightarrow$ & 400 & 一 & - \\
\hline 2 & Breast & $0 \cdot 50$ & ++ & 一 & 一 & - & 一 & 一 \\
\hline 3 & Bottle & 0.50 & - & - & 一 & 400 & 一 & - \\
\hline 4 & Breast & $0 \cdot 50$ & ++ & - & $<100$ & $<100$ & 一 & - \\
\hline 6 & Breast & $0 \cdot 75$ & ++ & - & - & - & 一 & 一 \\
\hline 7 & Breast & 0.50 & ++ & - & $<100$ & - & - & - \\
\hline 8 & Mixed & 0.50 & - & - & - & - & $<50$ & - \\
\hline 9 & Bottle & 0.50 & - & 400 & - & 100 & - & - \\
\hline 10 & Bottle & 0.50 & - & 200 & - & 100 & 一 & + \\
\hline 11 & Breast & 0.50 & 一 & - & 50 & - & - & - \\
\hline 12 & Bottle & 0.50 & - & 一 & - & 100 & - & - \\
\hline 13 & Bottle & 0.50 & ++ & - & 一 & - & - & - \\
\hline 14 & Breast & 0.50 & - & 一 & - & $<50$ & 一 & - \\
\hline 16 & Breast & 0.50 & - & - & $<100$ & 100 & - & - \\
\hline
\end{tabular}

TABLE IV

Sugar concentrations found by chromatography in the urine of 11 neonates

\begin{tabular}{|c|c|c|c|c|}
\hline \multirow{2}{*}{$\begin{array}{c}\text { Case } \\
\text { no. }\end{array}$} & \multirow[b]{2}{*}{ Feed } & \multicolumn{3}{|c|}{ Urine concentration $(\mathrm{mg} / 100$} \\
\hline & & Lactose & Glucose & Galactose \\
\hline $\begin{array}{r}1 \\
2 \\
3 \\
4 \\
5 \\
6 \\
7 \\
8 \\
9 \\
10 \\
11\end{array}$ & $\begin{array}{l}\text { Bottle } \\
\text { Bottle } \\
\text { Breast } \\
\text { Mixed } \\
\text { Bottle } \\
\text { Breast } \\
\text { Bottle } \\
\text { Bottle } \\
\text { Bottle } \\
\text { Bottle } \\
\text { Mixed }\end{array}$ & $\begin{array}{r}<50 \\
<50 \\
<50 \\
<50 \\
<50 \\
150 \\
50 \\
<50 \\
<50 \\
<50 \\
150\end{array}$ & $\begin{array}{l}\overline{<50} \\
- \\
= \\
- \\
100 \\
= \\
=\end{array}$ & $\begin{array}{l}- \\
- \\
- \\
\overline{1} \\
\overline{-} \\
- \\
-\end{array}$ \\
\hline
\end{tabular}

had detectable sugar in their stools. In 3 of these there was a significantly higher concentration of sugar in their stools.

\section{Discussion}

Firstly, this study confirms the observations of Davidson and Mullinger (1970) that a number of normal neonates have greater amounts of reducing substances in their stools than older normal infants. The failure of Soeparto et al. (1972) to find a higher level of reducing susbstances in their earlier study of neonates was probably due to the small number of controls. Secondly, this study confirms the existence of physiological mellituria in the newborn, some normal neonates having amounts of sugar in their urine greater than the $15 \mathrm{mg} / 100 \mathrm{ml}$ accepted as the upper limit for normal in older children.

The relationship between the Clinitest reaction and the amount of stool sugars estimated chromatographically was somewhat variable, but in all except three children lactose, glucose, or galactose, or a combination, were found. In these children the stool chromatographic findings must be interpreted as evidence of lactose malabsorption, colonic and faecal flora having split unabsorbed lactose into its component monosaccharides which are then metabolized to a variable degree (Lindquist and Wranne, 1976).

The explanation for the higher levels of these stool sugars in the normal neonate as compared to older infants thus seems to be a physiological 
malabsorption of lactose occurring during the newborn period, although the mechanism of such malabsorption is not clear, especially as lactose levels are usually fully mature at the time of gestation. In this study there was no correlation between the amount of sugar in the stool and the infant's gestation, but there was with the type of feeding. The trend for higher levels of reducing substances to be associated with breast feeding suggest that the higher level of lactose in breast milk may be one factor, although the different gut flora in breast- and bottle-fed infants may also play a role.

The 3 children who had $0.5 \%$ reducing substances in their stools but no lactose or monosaccharides had oligosaccharides or maltose on chromatography. Probably the stool oligosaccharides were of bacterial origin (E. H. Stobo and J. A. WalkerSmith, unpublished), but the maltose was of uncertain, possibly dietary origin. 2 children who had lactose in their stools also excreted lactulose. This sugar originates from lactulose sometimes produced in the manufacture of infants foods as an unwanted by-product (Gerritsen et al., 1963). These findings show the value of stool chromatography in determining the exact nature of sugars present in the stool.

This study also confirms the well-known observation that breast-fed infants may pass acid stools, but it also showed that the stools of some normal bottle-fed neonates may be acid. Clearly a stool $p \mathrm{H}$ of less than 6 may not be abnormal in some neonates. But estimation of stool $p \mathrm{H}$ alone may be an unreliable screening test for sugar intolerance (Soeparto et al., 1972, Walker-Smith, 1973), though estimation of both stool $\mathrm{pH}$ and reducing substances in the stool provides information of diagnostic value (Ament, 1973).

It has been emphasized that stools should not be contaminated by urine in assessing sugar malabsorp- tion (Ament, 1972) but our study suggests that it is probably more important that urine should not be contaminated by stools. One of us (J.W-S.) has seen a child diagnosed incorrectly as diabetes mellitus because of such contamination.

We thank Mr. Victor Oberholzer and Mr. P. Hindoocha, Queen Elizabeth Hospital for Children, and the nursing staff of the Mother's Salvation Army Hospital for their assistance.

\section{RFFERENCES}

Ament, M. E. (1972). Malabsorption syndromes in infancy and childhood. Fournal of Pediatrics, 81, 685.

Ament, M. E. (1973). Screening tests for sugar malabsorption. fournal of Pediatrics, 82, 893.

Bickel, H. (1961). Mellituria, a paper chromatographic study. fournal of Pediatrics, 59, 641.

Davidson, A. G. F., and Mullinger, M. (1970). Reducing substances in neonatal stools detected by Clinitest. Pediatrics, 46 , 632.

Gerritsen, T., Lemli, L., Ptacek, L. J., and Waisman, H. A. (1963). The presence of lactulose in the urine of infants with lactosuria. Pediatrics, 32, 1033.

Haworth, J. C., and McCredie, D. (1956). Chromatographic separation of reducing sugars in the urines of newborn babies. Archives of Disease in Childhood, 31, 189.

Howat, J. M., and Aaronson, I. (1971). Sugar intolerance in neonatal surgery. Fournal of Pediatric Surgerv, 6, 719

Kerry, K. R., and Anderson, C. M. (1964). A ward test for sugar in faeces. Lancet, $1,981$.

Lindquist, B. L., and Wranne, L. (1976). Problems in analysis of faecal sugar. Archives of Disease in Childhood, 51, 319.

Menzies, I. S. (1973). Quantitative estimation of sugars in blood and urine by paper chromatography using direct densitometry. fournal of Chromatography, 81, 109.

Menzies, I. S., and Seakins, J. W. T. (1969). Chromatographic and Electrophoretic Techniques, Vol. 1., p. 310 . Ed. by I. Smith. Heinemann, London.

Soeparto, P., Stobo, E. A., and Walker-Smith, J. A. (1972). Role of chemical examination of the stool in diagnosis of sugar malabsorption in children. Archives of Disease in Childhood, 47, 56.

Walker-Smith, J. A. (1973). Screening tests for sugar malabsorption. Fotirnal of Pediatrics, 82, 893.

Correspondence to Dr. J. A. Walker-Smith, Queen Elizabeth Hospital for Children, Hackney Road, London E2 8PS. 